\title{
POTENCY TEST OF COMMERCIALLY AVAILABLE INACTIVATED NEWCASTLE DISEASE VACCINES IN SERBIA
}

\author{
Marina Žekić-Stošićc ${ }^{1}$ Radomir Ratajac ${ }^{1}$, Sava Lazić ${ }^{1}$, \\ Dušan Orlić ${ }^{1}$, Miloš Kapetanov ${ }^{1}$, Rajko Čebedžić ${ }^{2}$ \\ ${ }^{1}$ Scientific Veterinary Institute Novi Sad, Novi Sad, Serbia \\ ${ }^{2}$ Medicines and Medical Devices Agency of Serbia, Belgrade, Serbia
}

\section{Abstract}

In order to evaluate the efficacy of inactivated oil-emulsion Newcastle disease vaccine (commercially available on market in Serbia) we carried out the potency test in chickens, using hemagglutination inhibition (HI) test for detection of antibodies. The values of $\mathrm{HI}$ titers in the serum before and three weeks after vaccination revealed immunoconversion (IC) in chickens, and indicated potential differences in the immunoconversion values between two groups vaccinated with monovalent and polyvalent vaccine. In the period 2010-2012, 27 vaccines were tested, there of 21 polyvalent and six monovalent ones. Three weeks after the vaccination, $\mathrm{HI}$ titers of all vaccines were high. The average IC values were calculated as $\log _{2}$ (HI titer). The values ranged from 2.2 to 8.2 for polyvalent vaccine, whereas average values for monovalent vaccines were in the range from 3.2 to 6.3 . Three weeks post vaccination; no statistically significant differences were recorded in the immune response between the tested groups of birds (vaccinated with monovalent and polyvalent vaccines). This supports the fact that both tested vaccines demonstrated good potency to creating immunity against $\mathrm{ND}$ in vaccinated birds.

Key words: poultry, New Castle disease, vaccine, potency testing 


\title{
ISPITIVANJE AKTIVNOSTI INAKTIVISANIH VAKCINA PROTIV NEWCASTLE BOLESTI DOSTUPNIH NA TRŽIŠTU REPUBLIKE SRBIJE
}

\author{
Marina Žekić-Stošić ${ }^{1}$, Radomir Ratajac ${ }^{1}$, Sava Lazić ${ }^{1}$, \\ Dušan Orlić ${ }^{1}$, Miloš Kapetanov ${ }^{1}$, Rajko Čebedžić ${ }^{2}$ \\ ${ }^{1}$ Naučni institut za veterinarstvo „Novi Sad“, Rumenački put 20, Novi Sad, Srbija \\ ${ }^{2}$ Agencija za lekove i medicinska sredstva Srbije, Vojvode Stepe 458, Beograd, Srbija
}

\section{Kratak sadržaj}

$\mathrm{U}$ cilju procene efikasnosti inaktivisanih uljnih vakcina protiv Newcastle bolesti (NB) koje su komercijalno dostupne na tržištu Republike Srbije, sproveli smo ispitivanje aktivnosti vakcine, na kokoškama. Za detekciju antitela koristili smo test inhibicije hemaglutinacije (HI). Vrednosti titra hemaglutinacije u serumima, pre vakcinacije i 3 nedelje posle vakcinacije ukazuju na imunokonverziju, i na moguću razliku u vrednostima imunokonverzije izmedju grupe vakcinisanih polivalentnim vakcinama i grupe vakcinisanih monovalentnim vakcinama. U period 2010-2012., kontrolisano je dvadeset sedam vakcina: dvadest jedna polivalentna i šest monovalentnih vakcina. Tri nedelje nakon vakcinacije, HI titar je bio visok kod svih vakcinisanih jedinki. Prosečna vrednost za imunokonverziju je računata preko $\log _{2}$ (HI titer). Vrednosti imunokonverzije su bile u rasponu od 2,2 do 8,2 za polivalentne vakcine, dok je prosečna vrednost za imunokonverziju monovalentnih vakcina bila od 3,2 do 6,3. Tri nedelje nakon vakcinacije, nisu uočene statički značajne razlike u imuno- odgovoru ove dve grupe vakcinisanih jedinki (vakcinisane polivalentnim i vakcinisane monovalentnim vakcinama), što potvrdjuje i činjenica da sve kontrolisane vakcine pokazuju dobru aktivnost u stvaranju imuniteta protiv NB, kod vakcinisanih jedinki.

Ključne reči: živina, atipična kuga živine, vakcine, ispitivanje aktivnosti vakcina

\section{INTRODUCTION}

Newcastle disease (ND) is one of the diseases listed in the OIE register. ND is caused by virulent strains of avian paramyxovirus type 1 (APMV-1) of the genus Avulavirus, belonging to the family of Paramyxoviridae. There are ten serotypes of avian paramyxoviruses (APMV-1 to APMV-10) (OIE Terrestrial 
Manual 2012). Since the first outbreak, when disease was recognized in poultry and termed ND in 1926, in Java, Indonesia, and in Newcastle-upon-Tyne, England, ND is enzootic in some parts of the world and one of the most important diseases of poultry worldwide.

ND occurs in both extensive and intensive way of farming. Strains of NDV have been grouped into five pathotypes based on the clinical signs seen in infected chickens: viscerotropic velogenic, neurotropic velogenic, mesogenic, lentogenic and asymptomatic (Alexander et Senne, 2008). One of the most characteristic properties of different strains of NDV has been their great variation in pathogenicity for chickens. This infection can spread via direct contact with secretions, especially feces, from infected birds or indirect contact through contaminated feed, water, equipment, vehicles, humans, fomites etc.

ND inflicts enormous economic consequences in poultry industry in many parts of the world: big percentage of mortality (it is not rare that all birds from flock die without manifesting of clinical symptoms, especially in the first 3 days of epizootic). Because of all this consequences and huge economic losses, the majority of commercial poultry flocks are involved in the program of control of ND. In Serbia, Newcastle disease has been present for many years. Last epidemic that occurred in our country was recorded in the Province of Vojvodina, during 2006 and 2007 (Milic et al., 2012).

Immunoprophylaxis is the only way in successful fight aganst the outbreaks of this disease. Vaccination programs differ from country to country. Prophylactic vaccination is applied on a large scale in the EU and elsewhere in the world. All member states except Sweden, Finland and Estonia apply a prophylactic vaccination policy. So far, the emergency vaccination was used only once in Italy, during an outbreak in 2001.

In accordance with the Program of animal health protection measures (2014) of the Republic of Serbia, in order to prevent the occurrence, spread and suppression of ND, every farm and backyard with poultry and game birds must be registered and recorded in the Central database. Poultry, game birds and pigeons in all keeping and breeding systems are vaccinated against ND for boosting the immunity, applying vaccines produced from the lentogen forms of virus. Control of the immune status after vaccination is to be performed by serological examination of blood serum. In cases of unfavorable epidemiological situation for poultry and game birds in intensive breeding, the composing Program of immunoprophylaxis is needed, which has to be subjected to the competent veterinary inspection. In broiler chickens in extensive farming conditions, vaccination must be done two times: at the age of one day in the incubator or at the place of destination, by spraying, and from 14 to 18 days 
of age in drinking water, by spray or by oculonasal application, according to the manufacturer's instructions. In poultry intended for the production of hatching and consumption eggs in extensive farming conditions, vaccination is performed four times: the first vaccination is carried out by spraying in incubator or at the place of destination, at the age of one day, and the remaining cycles at the age of three, six and twelve weeks, according to the manufacturer's instructions.

Several types of vaccines are available both worldwide and in our market: inactivated vaccines and the vaccines that contain live virus. Each of them has its advantages and disadvantages. Live vaccines are generally used to induce protection in young birds. Inactivated vaccines are used to booster the immune responses in layer flocks and to generate uniform protective antibody titers before the laying period. Inactivated ND vaccines are among the most widely used vaccines in commercial poultry worldwide (Ivo Claassen, 2011).

ND vaccine (inactivated) (also known as avian Paramyxovirus 1 vaccine (inactivated) for vaccines intended for some species) is a preparation of a suitable strain of ND virus (avian Paramyxovirus 1), inactivated while maintaining adequate immunogenic properties (European pharmacopoeia, $6^{\text {th }}$ Edition). At our market, two groups of inactivated vaccines are available: monovalent inactivated vaccines (PEST-OL ${ }^{\bullet}$, Veterinarski zavod Subotica; BRONED-OL ${ }^{\bullet}$, Veterinarski zavod Subotica) and polyvalent inactivated vaccines (PESTIKAL + EDS + IB, Genera; POLIVIROL-3, Veterinarski zavod AD Zemun; POLIVIROL-4, Veterinarski zavod AD Zemun) Nobilis ${ }^{\circledR}$ Reo+IB+G+ND, Intervet; Nobilis ${ }^{\circledR}$ IB + ND + EDS, Intervet; Bronipra ND/IBD, Hipra).

Biological products, such as vaccines, require batch-related quality control to ensure their safety and potency. Part of quality control is based on animal model; consequently, the use of laboratory animals is extensive. The aim of this research was to perform the quality control (potency test) of vaccines against $\mathrm{ND}$, for every batch, before placing them on the market in the Republic of Serbia. Monovalent and polyvalent vaccines were examined, offering an opportunity to compare the differences in immune response of chickens three weeks after the vaccination.

\section{MATERIAL AND METHODS}

In the period 2010-2012, twenty-seven vaccines were tested in the Scientific Veterinary Institute „Novi Sad“. During these three years (2010-2012), the potency tests were carried out on 21 polyvalent vaccines: PESTIKAL+EDS+IB (8 sample - batch), POLIVIROL-3 (3), POLIVIROL-4 (3), Bronipra ND/IBD 
(1), Nobilis ${ }^{\circ}$ eo $+\mathrm{IB}+\mathrm{G}+\mathrm{ND}$ (4), Nobilis $\mathrm{IB}+\mathrm{ND}+\mathrm{EDS}$ (2). Moreover, six monovalent vaccines were controlled during this period: $\mathrm{PEST}^{-O L^{\circ}}(3)$ and $\mathrm{BRO}-$ NED-OL ${ }^{\circ}$ (3).

Potency testing of vaccines was performed in accordance with the method described in European Pharmacopeia, monograph 01/2008:0870 for inactivated vaccine for Newcastle disease (Vaccinum pseudopestis aviariae inactivatum) with certain modifications.

For each batch of the vaccine, a potency test has been carried out by using 10 chickens, 21-28 days old, which did not have antibodies against the causative agent of ND. Each chicken has been vaccinated by the intramuscular application with a vaccine volume equivalent to $1 / 50$ of a dose. Blood samples were taken before vaccination and 21 days after vaccination. The specific antibodies titers were detected by haemagglutination-inhibition (HI) test. The HI test is carried out by using series of the investigated blood serums (two-fold dilution in saline solution). The same volume (four hemaglutination units- $25 \mu \mathrm{L}$ ) of reference ND virus (La Sota strain) is added to every dilution of the serum. After incubation of 30 minutes, $50 \mu \mathrm{L}$ of $0.5 \%$ suspension of red blood cells (derived from younger chickens, free of antibodies against the ND) was added to each dilution of the serum with added virus. The results were read after 45 minutes of incubation. Based on the results of the HI test, we defined the IC values as the difference between the values of the titer before and 3 weeks after vaccination, calculated as $\log _{2}$ (HI titer). Vaccinated animals were monitored daily to determine the health status.

Biostatistical analysis of the results was performed using Student's t-test. To assess the significance of differences between the immune response of chickens vaccinated with monovalent and polyvalent vaccines, two-sided Student's t-test (Ms Office Excel 2010) was used, normally distributed. The standard deviation of the population is not known, thus the standard deviation of the sample was applied.

\section{RESULTS AND DISCUSSION}

The examined vaccines were distributed into two groups (depending on the prevalence - antigenicity of the vaccine). This method enabled simpler analysis and comparison of the obtained seroconversion results in the HI test. The first group is a group administered polyvalent vaccine- $77.8 \%$ of all tested vaccines (2010- 5 samples; 2011- 8 samples; 2012- 8 samples). The second group encompassed birds receiving monovalent vaccines- $22.2 \%$ of all tested vaccines (2010- 2 samples, 2011- 2 samples, 2012- 2 samples). 
The results are shown in chronological order (Table 1) through years: 2010, 2011 and 2012, and classified as monovalent and polyvalent.

Table 1. A chronological review of vaccine potency tests (immunoconversion) in chickens

\begin{tabular}{|c|c|c|c|c|c|c|}
\hline \multirow{4}{*}{ 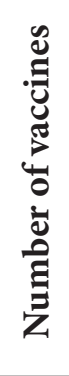 } & \multicolumn{6}{|c|}{ Year of testing } \\
\hline & \multicolumn{2}{|c|}{2010.} & \multicolumn{2}{|c|}{2011.} & \multicolumn{2}{|c|}{2012.} \\
\hline & \multicolumn{6}{|c|}{$\begin{array}{l}\text { Antigenicity of vaccines / values of immu- } \\
\text { noconversion (log2(HI titer)) }\end{array}$} \\
\hline & $\begin{array}{c}\text { polyva- } \\
\text { lent } \\
\text { vaccines }\end{array}$ & $\begin{array}{c}\text { mono- } \\
\text { valent } \\
\text { vaccines }\end{array}$ & $\begin{array}{c}\text { polyva- } \\
\text { lent } \\
\text { vaccines }\end{array}$ & $\begin{array}{c}\text { mono- } \\
\text { valent } \\
\text { vaccines }\end{array}$ & $\begin{array}{c}\text { polyva- } \\
\text { lent } \\
\text { vaccines }\end{array}$ & $\begin{array}{c}\text { mono- } \\
\text { valent } \\
\text { vaccines }\end{array}$ \\
\hline 1 & 6.5 & 6.3 & 4.5 & 4.4 & 2.5 & 5.6 \\
\hline 2 & 6.2 & 3.2 & 8.2 & 3.7 & 3.4 & 5.5 \\
\hline 3 & 6.0 & & 4.1 & & 2.2 & \\
\hline 4 & 6.7 & & 4.9 & & 5.2 & \\
\hline 5 & 3.4 & & 3.9 & & 2.9 & \\
\hline 6 & & & 2.6 & & 3.4 & \\
\hline 7 & & & 4.7 & & 3.0 & \\
\hline 8 & & & 5.3 & & 3.4 & \\
\hline$\overline{\mathbf{x}}$ & 5.8 & 4.7 & 4.8 & 4.1 & 3.3 & 5.6 \\
\hline SD & 1.35 & 2.21 & 1.61 & 0.49 & 0.90 & 0.07 \\
\hline
\end{tabular}

Legend: the average value $(\mathrm{x})$, standard deviation (SD)

The immunoconversion (IC) values after vaccination are shown in Table 1. Four polyvalent and two monovalent vaccines were submitted for quality control in 2010. During potency testing, values of IC in polyvalent vaccines were within the range from 6.0 to 6.7 and just one of four vaccines had slightly lower serological conversion (3.4). Values of IC in monovalent vaccines were 6.3 and 3.2. The average values for IC in polyvalent and monovalent vaccines were 5.8 and 4.7, respectively. In 2011, eight polyvalent and two monovalent vaccines were tested for quality control. Values of IC in polyvalent vaccines, during 
potency testing, were in the range from 3.9 to 5.3. Two of eight polyvalent vaccines had IC values out of this range: one had somewhat lower value (2.6), and the other one had slightly higher value (8.2). The results obtained of IC in monovalent vaccines were 4.4 and 3.7. The average value for IC in polyvalent vaccines was 4.8 and the average value for IC in monovalent vaccines was 4.1. In 2012, eight polyvalent and two monovalent vaccines were examined for quality control. During potency testing, results of IC in polyvalent vaccines were in the range from 2.5 to 3.4. Two of eight polyvalent vaccines had values out of this range: 2.2 and 5.2. The differences from initial to the final HI titers of two monovalent vaccines were 5.6 and 5.5. The average value for IC in polyvalent vaccines was 3.3 and the average value for IC in monovalent vaccines was 5.6.

Chickens vaccinated with polyvalent vaccines in 2010 and 2011 had higher values of IC, while in year of 2012, immune- response in chickens vaccinated with monovalent vaccines was more noticeable. The results of IC values were higher than 2 in all tested vaccines (27), indicating a sufficient activity of the vaccines (European pharmacopoeia, $6^{\text {th }}$ Edition). During this research, all chicken were without any clinical signs of ND or any other disease.

The values from Table 1 form two groups with different numbers of data: polyvalent vaccines $(\mathrm{N} 1=21)$ and monovalent vaccines $(\mathrm{N} 2=6)$. T-value $(\mathrm{t}=$ 0.58 ) is calculated based on mean values and standard deviations. The obtained result is compared with the values from the Student table of critical values.

When using $\mathrm{HI}$ to evaluate the immune response after vaccination, it should be taken into account that $\mathrm{HI}$ titers are greatly influenced by the quality of the vaccine, the route and method of administration, environmental and individual factors, but they also depend on health status of the individual birds. The quality of the vaccine and its efficacy is determined by all aforementioned factors.

Vaccine antigens are often combined to reduce the number of injections. It is well known that some vaccine antigens, such as the whole cell pertussis, enhance the potency of other vaccine antigens. Most of the vaccines include a number of substances, such as an adjuvant and a preservative, which may or may not affect the quality of the product. This unknown quality makes each batch of vaccine a unique product, and strict controls must be in place to ensure the safety and potency of each batch. A major part of the tests used for quality control is based on animal models, and consequently, the use of laboratory animals is extensive, particularly for vaccine quality control (Hendriksen CF, 2009). Due to the substantial number of animals used annually for the release of veterinary vaccines, global regulatory agencies actively encourage the evaluation, development, and implementation of novel approaches that reduce, refine, and replace (3Rs) the use of animals in evaluating vaccine safety and 
potency product release testing. The development of an in vitro potency assay for inactivated NDV vaccines would save time, expenses, and use of experimental animals (K.A. Liljebjelke et al., 2008).

The most widely used tests for quality control of vaccines include in vivo potency tests. Typically, those tests evaluate the protective or immune response to the complete vaccine, including antigenic material (e.g., adjuvants, excipients). In vitro antigen quantification has some scientific and psychological limitation, because that is only a measure of antigen quantity, and not necessarily of biological activity (Hendriksen CF, 2009). Many typically used adjuvants, such as mineral oil and aluminum salts, may interfere with in vitro quantification methods. The challenges caused by the adjuvants that are present in many veterinary vaccines present one of the key technical issues. Therefore, these adjuvants should be separated from the antigenic component of the vaccine before in vitro potency testing. Since the adjuvant is a critical component for developing the appropriate protective response for inactivated vaccines, additional in vitro tests may be required to ensure their quality. Regardless, when antigen quantification methods are developed, the effect of an adjuvant on the immunogenicity of the protective antigen also needs to be investigated (Jodie Kulpa-Eddy et al., 2011).

Another approach, which still relies on the use of animals, is the replacement of the challenge procedure by serology. Unfortunately, in vitro serological methods are not feasible alternatives in vaccine - induced protection cases, based on both humoral (antibody) and cellular responses (Hendriksen CF, 2009).

For many veterinary vaccines, regional differences affect the availability and implementation of in vitro replacement assays. For example, the USDA published an in vitro ELISA potency test for inactivated swine erysipelas vaccine (Erysipelothrix rhusiopathiae), while the European Directorate for the Quality of Medicines \& HealthCare (EDQM) published a mouse-based serology test in the European Pharmacopoeia (Ph. Eur.). The EDQM has developed, validated, and approved an in vitro test for inactivated Newcastle disease vaccine that is not a standard requirement in the United States.

Due to the successful international communication, number of Replacement methods for veterinary vaccines that will be available and accepted for use may increase.

However, although these results are satisfactory, it is evident that despite vaccination, the epidemic continues to emerge. Recurrent outbreaks of ND despite vaccination have raised the question whether currently used ND vaccines are still adequate, not only for the protection against clinical disease, but also for the inhibition of virus transmission (Kapczynski et King, 2005). 
However, the increasing development of molecular biology favors the development of an effective vaccine, such as a recombinant vaccine that would initiate protective immunity at a satisfactory level.

Poultry vaccines are of highest priority for further development of alternative replacement methods for quality control testing. The growing role of international organizations such as the International Cooperation on Harmonization of Technical Requirements for Registration of Veterinary Medicinal Products (VICH) and the World Organization for Animal Health (Office International des Epizooties - OIE) is apparent. The harmonization of guidelines and reference standards for broad use of the vaccines would probably increase the interaction between those organizations and the national regulatory groups. This harmonization will make the implementation of the 3 Rs for vaccine product release more realistic. Although the vaccine companies must develop and validate productspecific assays, the reference standards would provide the basis for their further development and validation (Jodie Kulpa-Eddy et al., 2011).

\section{CONCLUSION}

All vaccines (both polyvalent and monovalent) that were included in potency testing (2010-2012) provide good protection of chickens from ND.

In the year of 2010, the average value for IC in polyvalent vaccines was 5.8 and the average value for IC in monovalent vaccines was 4.7. In the year of 2011, the average value for IC in polyvalent vaccines was 4.8 and the average value for IC in monovalent vaccines was 4.1. In the year of 2012, the average value for IC in polyvalent vaccines was 3.3 and the average value for IC in monovalent vaccines was 5.6.

Realized value of the Student T-test $(t=0.58)$ is less than tabular values for confidence level $\mathrm{P}=95 \%$, as well as the confidence level $\mathrm{P}=99 \%$. Thus, we may conclude that there is no statistically significant difference between the values obtained for immunoconversion results of polyvalent and monovalent vaccines. Consequently, there was no statistically significant difference between the values obtained after vaccination with polyvalent and monovalent vaccines.

\section{AKNOWLEDGMENTS}

This work was supported by a grant from scientific project TR 031071 of Ministry of Education and Science of Republic of Serbia. 


\section{REFERENCES}

1. Alexander D., Senne D.: Newcastle disease. Other avian paramyxoviruses, and pneumovirus infections, Disease of poultry.12th Edition, Ames, Iowa State University Press, pp75-116, 2008

2. European Pharmacopoeia, 6th ed. Monograph 01/2007:0870. Strasbourg, France: European Department for the Quality of Medicines \& HealthCare (EDQM), Council of Europe, 2007.

3. Hendriksen CF: Replacement, reduction and refinement alternatives to animal use in vaccine potency measurement. Expert Rev Vaccines, $8(3): 313-22,2009$

4. Claassen Ivo: Case study of development, validation, and acceptance of a non-animal method for assessing veterinary vaccine potency, Procedia in Vaccinology, 5, 175-183, 2011,

5. Kulpa-Eddy Jodie, Srinivas Geetha, Halder Marlies, Hill Richard, Brown Karen, Rothe James, Draayer Hans, Galvin Jeffrey, Claassen Ivo, Gifford Glen, Woodland Ralph, Doelling Vivian, Jones Brett, S Stokes William: Non-animal replacement methods for veterinary vaccine potency testing: state of the science and future directions, Procedia in Vaccinology, 5, $60-$ 83,2011

6. Liljebjelke K. A., King D. J., Kapczynski D. R.: Determination of minimum hemagglutinin units in an inactivated Newcastle disease virus vaccine for clinical protection of chickens from exotic Newcastle disease virus challenge, Avian Disease, 52, 260-268, 2008

7. Kapczynski D., King D.: Protection of chickens against overt clinical disease and determination of viral shedding following vaccination with commercially available Newcastle disease virus vaccines upon challenge with highly virulent virus from the California 2002 exotic Newcastle disease outbreak. Vaccine, 16, 23, 26, 3424-33, 2005

8. Milic N., Lazic S., Vidanovic D., Sekler M., Nisavic J., Resanovic R. and Petrovic T.: Molecular characterization of some strains of Newcastle disease virus isolated in province of Vojvodina, Republic of Serbia, Acta Veterinaria (Belgrade), 62, 4, 365-374, 2012 
9. OIE: Manual of diagnostic tests and vaccines for terrestrial animals: mammals, birds and bees, in Biological Standards Commision. Paris, World Organization of Animal Health, 2012, vol 1, part 2, Chapter 2.03.14.,1-19

10. Pravilnik o utvrđivanju programa mera zdravstvene zaštite životinja za 2014. godinu, Službeni glasnik RS, 24/2014

Primljeno: 15.08 .2014 .

Odobreno: 20.10.2014. 